Gynäk. Rdsch. 1973;13:314

\title{
Ergänzung zum Artikel von H.-D. Hiersche
}

Wann entsteht Leben?

Nachdem die Arbeit von der Redaktion angenommen war, hatte der Autor nachträglich das Manuskript eines Zusatzes eingesandt, der nach Auffassung der Redaktoren eine Einmischung in deutsche politische Verhältnisse darstellte, die nicht in eine medizinische Zeitschrift gehört. Aus diesem Grunde wurde dieser Nachtrag nicht veröffentlicht. Auf besonderen Wunsch des Autors ist die Redaktion nun doch bereit, diesen Text nachstehend abzudrucken.

Addendum

(Gynäkologische Rundschau, Vol. 13, No. 3, pp. 212-218) 